Vol. 2, No. 2, Juli 2018, 129-135

Available Online at https://ejournal.warmadewa.ac.id/index.php/kulturistik DOI: dx.doi.org/10.22225/kulturistik.2.2.719

\title{
IDENTIFYING THE TYPES OF ACCOUNTING TERMS IN ENGLISH ACCOUNTING BOOK AND THEIR EQUIVALENCES IN INDONESIAN
}

\author{
R. Guntur Mahardika \\ Universitas Udayana \\ rm.gunturmahardika@gmail.com \\ I Nyoman Sedeng \\ Universitas Udayana \\ nyoman_sedeng@hotmail.com \\ Ni Luh Nyoman Seri Malini \\ Universitas Udayana \\ kmserimalini@yahoo.com
}

\begin{abstract}
Translation has important role to the development of science field, especially in accounting field which has been expanding in this globalization era. Hence, it is very interesting to analyze the translation of English accounting terms into Indonesian because it contains many accounting typical terms and specific vocabulary usually used by accountant. Furthermore, this research focuses on identifying of accounting terms in English accounting book and their equivalences in Indonesian. The data was collected by note taking and comparing techniques. Then, the data analysis is performed to search the form and category of the English accounting terms. Parallel corpora were used in presenting source language and target language data. Descriptive qualitative methods were applied to analyze all research problems. The theory of translation techniques proposed by Molina and Albir (2002) was applied in order to find translation techniques chosen by translator in translating English accounting terms and the theory of grammatical proposed by Quirk et al (1985) to find the categories of word, compound word and phrase. This research is expected to contribute to further research related to accounting vocabularies consist of a set of_words, compound words and phrase_which_are_considered_available_in_all languages_of the world.
\end{abstract}

Keywords: accounting terms, equivalence and techniques of translation

\section{INTRODUCTION}

Nowadays there is an increasing necessity of translation of accounting due to international business development and growing for foreign business markets. Given that the business interaction of multilingual companies in different countries implies constant communication and reporting, translation of accounting texts has become one of the most popular types of translation. "Accounting is much more than numbers", therefore translating in accounting terms is not an easy process because the fact that the accounting terms do not have their equivalent in the TL. As well, the translation technique of accounting terms influence the accuracy of translation as the goal of an ideal translation (Cartland, 2009: 3). 
Translation itself plays an important role in global communication. It involves at least two languages, source language and target language. Furthermore, translation is a bridge to connect two different cultures by the conversion of linguistic system, a medium that enables people to interact well with others coming from different cultural and linguistic backgrounds. In translating texts with certain terms, translators must have knowledge pertaining to the terms itself for example in translating financial statement. Further, translation is the replacement of a representation of an equivalence text in a second language. Text in different language can be equivalent in different degrees (fully or partially), in terms of different levels of presentation (equivalent in the context, semantics, grammar, lexis.) and at different ranks (word-for-word, phrase-for-phrase, sentence-forsentence)(Bell. Roger, 1991: 6).

"Accounting is an evolving profession, and many financial terms do not have narrow, precise definitions but by familiarizing yourself with them you will be well on the way to get the most from your business, finance and accounting courses"(Cartland, 2009: 4). Meanwhile, Hermanson indicated: Accounting principle courses teach you the "language of business" so you understand terms and concepts used in business decisions. If you understand how accounting information is prepared, you will be in even stronger position when faced with a management decision based on accounting information (Hermanson \& Al., 2001).

Scientific translation such as like accounting term is not like other translations, it goes beyond just rendering words from one language into another. It is rather considered a tool that helps people around the world develop and progress in the field of science. Thus a translator needs to ensure an accurate delivery of information and shows faithfulness and commitment to the source and the target language in accounting field, so that the translation information can be used easily and help in developing other countries.

One of the main problems that translation students may face is how to deal with translating scientific terms from English into Indonesian, especially in understanding common economic terms. Translation has a process in changing the language from original written text into verbal target language. Thus, translator needs the ability as well as knowledge to convey the meaning of the source language text to the target language readers. Hatim and Munday said that the term translation itself has several meaning: it can refer to the general subject field, the product (the text that has been translated) or (the act of producing the translation, otherwise known as translating) (Hatim \& Munday, 2004). The process of translation between two different written languages involves the translator changing an original written text (the source text or ST) in the original verbal language (the source language or SL) into a written text (the target text or TT in a different verbal language (the target language or TL)". (Hatim \& Munday, 2004: 4).

Due to the different perspectives of translation above, there are two main focuses as the definition of translation. First, it focuses on the process of translation itself, which indicates how the translator transfers the SL into TL equivalency. The second, it focuses on the product of translation produced by the translator. The translator should be familiar and understand their meanings as it is often underlined that the main difficulty to fully understand technical text and he or she needs some strategies, procedures and techniques in translating accounting terms of one language to another language in order to produce a 
comprehensive text for the target reader so that reader will understand the accounting terms applied in the text. This study of English accounting terms are characterized using in word level, compound word level and phrase level and followed by the Indonesian translation explanation to have comparison in form of English accounting terms. However the data were analyzed and described based on the technique of translation by applying the theory proposed by Molina and Albir (Molina \& Hurtado, 2002).

\section{RESEARCH METHOD}

The data of accounting terms used in this study were taken from the source texts book "Intermediate Accounting" for twelfth edition by Donald E. Kieso, Jerry J. Weygandt and Terry D. Warfield (2007)and the source text book "Akuntansi Intermediate" for seventh edition which was translated by Herman Wibowo (1995) which only dealt with accounting terms. Those books were chosen as the data source since it contained many accounting terms.

In conducting a research, the application of certain method is required. This study was applying qualitative research approach or qualitative method. The qualitative research was applied as the qualitative data; one English textbook with its Indonesian version was used as the data source of this study. The research conducted by observing the English accounting book into Indonesian. The reasons why those books were chosen are the fact that the translation of these two sources provide and contain many accounting terms. Furthermore, knowing the term of accounting and the difference the terms between English and Indonesian version was an interesting study. In addition, there was a lot of information concerned with translation phenomena, in terms of technique of translation especially in translating the accounting terms. The explication of both SL and TL would give a clear explanation of the meaning. The last was that this book contained a lot of data which were relevant to the problems discussed and analyzed in this study.

This study applies descriptive qualitative method and the goals are to investigate and describe the facts concerning the object of the study. The accounting terms having word, compound word and phrase which are found in English SL into Indonesian TL are categorized based on the theory that is proposed by Quirk et al. (1976) and (1985). Those terms are analyzed by the techniques of translation by Molina and Albir (2002) and Larson (1998). Those theories are available to analyze this data of English accounting terms by applying the descriptive and qualitative methods. Finally, the application of methods and theories in analyzing the data are able to determine the result of this study.

\section{DISCUSSION}

As point of view of linguistic, the term of accounting can be classified into three items, those are: 1.) accounting terms in word level and its equivalence into Indonesian, 2.) accounting terms in compound word level and its equivalence into Indonesian, and 3.) accounting terms in phrase level and its equivalences into Indonesian. The description of the types of English accounting terms can be drawn in the following figures.

\section{Accounting Terms in Word Level (Addition)}

The definition of accounting terms as words consist of one word only 
Vol. 2, No. 2, Juli 2018, 132

Available Online at https://ejournal.warmadewa.ac.id/index.php/kulturistik DOI: dx.doi.org/10.22225/kulturistik.2.2.719

according to the source of accounting term. The word will be explained in this data focus on the forms of deverbal nouns. Please see the details as below:

\begin{tabular}{|c|c|}
\hline Source Language & Target Language \\
\hline $\begin{array}{l}\text { Addition should present no major ac- } \\
\text { counting problems. }(492)\end{array}$ & $\begin{array}{l}\text { Penambahan haruslah tidak menimbulkan } \\
\text { masalah akuntansi yang besar. (673) }\end{array}$ \\
\hline
\end{tabular}

In the example above, the word addition is deverbal noun which is derived from verb add and suffix -ation. The equivalent of addition is the word penambahan which is derived from verb base tambah and the circumfix peN- $-a n$. The word penambahan belongs to noun class and it gets affixation of circumfix peN$-a n$. Therefore, the word addition in Oxford dictionary is noun category both in source language and target language (penambahan). Thus, English utterances mean the process of adding two or more numbers together to find their total.

The word penambahan in KBBI in the SL denotes the meaning of proses, cara, perbuatan menambahkan, this definition has the same meaning from the meaning of addition by indicating the process (proses) of adding (menambahkan). Seeing the meaning of the word penambahan, it is right that the word penambahan which is used as a noun expresses condition addition. In the word penambahan also gives the same situational features as given by the word addition. So we can say that the word addition is well translated into Indonesia.

\section{Accounting Terms in Compound Word (Close) Level (Extraordinary)}

Close form is the form in which the words are melded together, such as markdown and extraordinary. Please see the explanation the data as described below:

\begin{tabular}{cc}
\hline Source Language & Target Language \\
$\begin{array}{c}\text { Extraordinary items indicate unusual } \\
\text { and infrequent material gains and } \\
\text { losses (131) }\end{array}$ & $\begin{array}{c}\text { Pos-pos luar biasa mengindikasikan keun- } \\
\text { tungan dan kerugian besar yang tidak biasa dan } \\
\text { tidak sering terjadi (187) }\end{array}$ \\
\hline
\end{tabular}

The term extraordinary is written by no space and hyphen between extra and ordinary. Extra means something that is added especially to make a product, service, etc. and ordinary means the unusual condition or thing, thus extraordinary is very unusual and extremely good or impressive. This compound word extraordinary is not separated, there are melded together to reach the meaning. On the other hands, the word extraordinary is not rendered as the same form in Indonesian, because it is translated into open compound word luar biasa with separated by space but has the same meaning and feature as extraordinary. In conclusion, the writing of English compound word extraordinary does not interlard the Indonesian translation because the concept is delivered in both and so is the category. 
Vol. 2, No. 2, Juli 2018, 133

Available Online at https://ejournal.warmadewa.ac.id/index.php/kulturistik DOI: dx.doi.org/10.22225/kulturistik.2.2.719

\section{Accounting Terms in Compound Word (Hyphenated) Level (Cost- benefit)}

The hyphenated form using hyphen to separate the words is exemplified by cost-benefit. These compound words form will be described as below details:

\begin{tabular}{|c|c|}
\hline Source Language & Target Language \\
\hline $\begin{array}{l}\text { Cost-benefit relationship is the costs of } \\
\text { providing the information against the ben- } \\
\text { efits that can be derived from using it. (p. }\end{array}$ & $\begin{array}{l}\text { Hubungan biaya manfaat adalah biaya } \\
\text { untuk menyediakan informasi harus dihi- } \\
\text { tung bersamaan dengan manfaat yang } \\
\text { diterima dari penyediaan informasi terse- } \\
\text { but. (p. } 66 \text { ) }\end{array}$ \\
\hline
\end{tabular}

The hyphenated compound word has the characteristic with separated by hyphen as the separation sign. The example of hyphenated word is cost-benefit by using hyphen to replace space and to avoid the misunderstanding of the word meaning, it means ending, especially for the relationship. While its equivalence in Indonesian is translated into biay a manfaat and it is written separately by space, however word class is still noun compound word. It can be said that English compound words will not always be translated into the same form of translation of English accounting terms; it may be a close compound word or open compound word. In conclusion, the term cost-benefit is equivalent to biaya manfaat represent the same meaning and utterance.

\section{Accounting Terms in Compound Word (Open) Level (Adjusting entry)}

The open form is exemplified by adjusting entry. This open form of these compound words are as follows:

\begin{tabular}{cc}
\hline Source Language & Target Language \\
Adjusting entry is an entry made at & Ayat penyesuaian merupakan ayat-ayat yang \\
the end of an accounting period to & dibuat pada akhir periode akuntansi untuk \\
bring all accounts up to date on an & memutakhirkan semua perkiraan atas dasar \\
accrual basis, so that the company & akuntansi akrual sehingga laporan keuangan \\
can prepare correct financial state- & yang benar dapat disusun. (p. 94) \\
ment. (p. 63) & \\
\hline
\end{tabular}

The compound word is included in open form by space separation to distinguish the meaning. The compound word adjusting entry has the same form in its equivalent of Indonesian as ayat penyesuaian. Adjusting entry consists of word adjusting means to change in order to word or do better in a new situation and entry means a place for entering something. The two words adjusting and entry have different meaning but they are put together and separated by space, while there is any differentiation meaning and perception between the compound word adjusting entry than each word. The compound word adjusting entry itself means a journal entry recorded at the end of an accounting period to alter the ending balances in various general ledger accounts (A Dictionary of Accounting: 2016) which this definition has the same meaning as Indonesian equivalent ayat penyesuaian. 
Vol. 2, No. 2, Juli 2018, 134

Available Online at https://ejournal.warmadewa.ac.id/index.php/kulturistik DOI: dx.doi.org/10.22225/kulturistik.2.2.719

\section{Accounting Terms in Phrase Level (a note received for goods and ser- vices)}

The definition of accounting terms as phrase consists more than one word according to the source of accounting term. All items placed after the head is called as postmodifiers (Quirk \& Greenbaum, 1985: 65). They are notably divided into some types of noun phrase; noun phrase with finite clauses as postmodifiers, noun phrase with nonfinite clauses as postmodifiers and noun phrase with prepositional phrase as modifiers. However there is only noun phrase with prepositional phrase as modifiers found in my data. Please see the details as below:

\begin{tabular}{cc}
\hline Source Language & Target Language \\
When a note received for goods and & Bila wesel yang diterima untuk barang dan \\
services in a bargained transaction & jasa dalam suatu transaksi pertukaran yang \\
entered into at arm's length, (p. 330) & istimewa, (p. 437) \\
\hline
\end{tabular}

Postmodified NP in ST

: $\frac{\text { a note received for goods and services }}{\mathrm{a}}$

Postmodified NP in TT

$\frac{\text { wesel yang diterima }}{\mathrm{a}} \frac{\text { untuk barang dan jasa }}{\mathrm{c}}$

Based on the tree diagram of NP above a note received for goods and services, it is described that this NP has constituents of determiner (a as article), head (note as noun) and postmodifier (for goods and sevice as PP). Preposition for in PP for goods and services is used to indicate something given to.

NP a note received for goods and services is translated into wesel yang diterima untuk barang dan jasa which has constituents of head (wesel as noun) and postmodifier (yang diterima untuk barang dan jas a as relative pronoun). From the tree diagram, it is showed that the phrase class of postmodifier of for goods and services has been changed from prepositional phrase into relative clause. Although there is any change category from prepositional phrase into relative clause, but the meaning is equivalent in both texts.

\section{CONCLUSION}

This research discusses the categorization of English accounting terms in accounting intermediate reference book. And based on the finding of the analysis, the conclusions can be drawn: 1) accounting terms in word level, 2.) accounting terms in compound word level, and 3.) accounting terms in phrase level and its equivalent in Indonesian. Moreover, the researches data analysis which describe about the grammatical category of the terms such as word, compound word and phrase in accounting terms. Meanwhile, there are many differences of types of accounting types in terms in specification and in translation process but it gives many varieties in translating text of accounting terms. Furthermore, this research does not only serve a structural point of word, compound word and phrase in accounting terms but also the meaning is rendered into Indonesian. The meaning from source language into the target language will explain to the readers that 


\section{Lisulturisistinlk \\ KULTURISTIK JURNAL BAHASA \& BUDAYA}

Vol. 2, No. 2, Juli 2018, 135

Available Online at https://ejournal.warmadewa.ac.id/index.php/kulturistik

DOI: dx.doi.org/10.22225/kulturistik.2.2.719

English accounting terms have many aspects in translating, such as the form in source language must be same as the form in target language.

\section{REFERENCES}

Bell, R. (1991). Translation and translating: theory and practice. New York: Longman.

Cartland, S. M. (2009). See it, understand it, use it: accounting definition. Ontario: General Accountants of Ontario.

Hatim, B., \& Munday, J. (2004). Translation: an advance resource book. London: Routledge.

Hermanson, D. R., \& Al., E. (2001). Are America's top businesses students steering clear of accounting? Ohio CPA Journal, 54 (2), 26-30.

Kieso, D. E., \& et. al. (2007). Intermediate A ccounting (Twelfth Ed). New Jersey: John Wiley \& Son (Asia) Pte Ltd.

Larson, M. L. (1998). Meaning-Based Translation. A Guide to Cross- Language Equivalence (Second Edi). Lanham: University Press of America, Inc.

Molina, L., \& Hurtado, A. (2002). Translation technique revisited: A dynamic and functionalist approach. Meta Translator's Journal, XLVII, No.

Quirk, R., \& Greenbaum, S. (1985). A university grammar of English. England: Longman House Burnt Mill, Harlow.

Wibowo, H. (1995). A kuntansi Intermediate. Jakarta: Binarupa Aksara. 